\title{
Students' Perspective on Teaching Materials of English For Management Business II In Management Department, Universitas Muria Kudus
}

\author{
Nuraeningsih \\ University of Muria Kudus \\ nuraeningsih@umk.ac.id
}

\begin{abstract}
In the era of globalization, people around the world can have interaction for satisfying their goal in any aspect of life, such as business, politics, social and culture, education, etc. for that reason, the need of English proficiency as a global language becomes a priority. Therefore, it is compulsory for all students in formal education to learn it. In university level, students of the non-English department must study English with varied purposes, depending on their major, at least for two credits. Generally, it is taught to support the basic major or discipline. Consequently, the materials are designed based on their needs, especially later when they get jobs. For this reason, the material adapted is called ESP (English for Specific Purposes) which aims at preparing students to meet the demands of the workplace, i.e. the English skills. It should be more contextual, real life for now and the future. If the material is authentic and in accordance with the needs of learners, they will likely be ready to work as the demands of the employer. With these objectives, the English materials need to be adjusted to the needs of users (stakeholders) so that after graduating from universities, freshmen can directly work or create jobs according to their expertise. This research aims to describe students' perception of English teaching materials for Management department. A survey was conducted to second-semester students of Management department of Universitas Muria Kudus. The result of the study reveals that the students have a positive perspective on the teaching materials of English for Management Business II. They think affirmatively that the materials have been selected properly in terms of material attraction, usefulness, authenticity, variety, level of difficulty, language skill proportion and the discussed topics. In other words, the materials are appropriate for satisfying Management department students' need to prepare their future. The implication is the materials should be revised by adding more reading texts of Business English and providing more vocabulary tasks in the real context.
\end{abstract}

\section{ARTICLE HISTORY}

Received 14 February 2019

Accepted 2 May 2019

\section{KEYWORDS}

Teaching material; english for management business II

\section{Introduction}

In the era of globalization, people around the world can have interaction for satisfying their goal in any aspect of life, such as business, politics, social and culture, education, etc. for that reason, the need of English proficiency as a global 
language becomes a priority. Therefore, it is compulsory for all students in formal education to learn it, starting from elementary school until universities. Although the curriculum changes for several times, the position of English is regarded permanently exist.

In university level, students of a non-English department must study English with varied purposes, depending on their major, at least for two credits. Generally, it is taught to support the basic major or discipline. Consequently, the materials are designed based on their needs, especially later when they get jobs. For this reason, the material adapted is called ESP (English for Specific Purposes) which aims at preparing students to meet the demands of the workplace, i.e. the English skills. It should be more contextual, real life, and the here and now. If the material is authentic and in accordance with the needs of learners, they will likely be ready to work as the demands of the employer. With these objectives, the English materials need to be adjusted to the needs of users (stakeholders) so that after graduating from universities, freshmen can directly work or create jobs according to their expertise.

As the curriculum said, students of Management Department must join the English class in the first semester and second semester with 2 credits in each semester. The syllabus states that the aim of English learning is to enable students to communicate in English fluently and acceptably covering four language skills in intermediate level in management business field. To deal with this, the department assigns management department lecturers to teach English classes in the first semester and appoints English lecturers in the second semester. They select and design the materials by themselves every semester. However, there has been no research conducted to evaluate how the teaching material is. Since students are those who use it, it is important to know their opinion about the materials they learn. Whether or not it is relevant with the aim, it is necessarily conducted research to investigate how students perceive the topics taught and how useful they are for them. Therefore, the writer conducted research entitled "Students Perspective on Teaching Materials of English for Management Business II".

By conducting this research, it possibly yields some contributions to the improvement of teaching English as a foreign language in general. Hopefully, it can enrich the theory of teaching English and give practical input for English teachers in developing teaching materials. Thus, the result of the research will be very beneficial to make the materials more relevant and meaningful for students.

\section{Teaching English to Management Department Students of UMK}

English is taught to Management department students in the first and second semester with two credits for each. It aims to enable students to communicate in English fluently and acceptable in an intermediate level, especially in the management business field, covering four language skills: listening, speaking, 
reading and writing. In the first semester, the lecturers who are in charge are from Management department, then in the second semester, the classes are taught by English lecturers.

Since the students come with various capabilities, the challenge of English teaching becomes higher. The demand to provide fun learning is always addressed to make them encouraged to get involved in the teaching and learning process. Furthermore, the big number of students gives consequences to design interesting learning activities which involve all students. There are around 48 students per class.

\section{Teaching Materials of English for Management Business II}

As one of teachers' duty, teaching materials are designed by the teacher him/herself. Generally, s/he selected the materials from several sources and compiled. Ideally, it is designed by considering many things, such as relevant topics to its major, level of difficulty, contextual, etc. According to Dubin \& Olshtein (2000), teaching materials should be developed by providing clear teaching objectives and detailed teaching procedures. Therefore, when it is taught by different instructors, they will do the same thing and the result will not be far different. The materials of English for Management Business covers some topics, such as English for basic daily use, Company Structure, Trading, Employment, Money, and Advertisement. They are taught in 14 meetings.

\section{Need Analysis}

Needs analysis has an important role in the process of designing and implementing language education both ESP (English for Specific Purposes) or General English Course. ESP is a design approach must consider the needs of learners, as stated by Algadrie (2002) that by using need analysis, students can focus on what they want to learn. Needs of the students seen in the formatting requirements analysis framework that includes the target situation and learning needs framework. In the analysis of the target situation, A. Waters (1987) says that the language needed for several things: to study, to work, to training, or a combination of all three, or for other purposes such as status, test, and others. This gives the consequence that in designing the language material (read English) should be tailored to the needs of learners. Within the scope of vocational, teaching materials designed specifically according to their expertise. English skills taught in the program engine are quite different from English that is taught in the program of electrical expertise. Furthermore, A. Waters (1987) explains: 1) how language is used if the speaking, reading, writing, etc. by means of the telephone or face to face, 2) type of text or discourse that is used as an example is a technical manual, catalogs, informal conversations, etc., 3) Fill material covers the field of machinery, shipping, etc., 4) level for technicians, craftsmen, students, etc., 
5) in which the language is used whether in the office, in hotels, in the garage, or in the factory.

\section{Previous Research}

Some similar research has been conducted. One was conducted by Liau \& Chen (2012). They investigated teaching materials on Science and Technology. Their findings showed that students have a positive attitude, a careful examination in statistics and some parts of the materials which should be improved. The second is a study which was conducted by Esmer et al. (2016) on how education faculty students perceive on teaching methods and materials. Their respondents said that the most effective teaching methods are case studies and discussion. While the most effective teaching materials are film demonstration.

Another research on developing teaching materials was conducted by Farani (2017) who wrote an English workbook for students of D3 Accounting of Economics and Business Faculty University of Merdeka Malang through a Research and Development.

\section{Research Methodology}

As the objective of the research was to describe students' perception of teaching materials of English for Management department, this research was classified as descriptive research. To get the answers of the research questions, a survey was distributed to second-semester Management department students in academic year 2015/2016. There were 336 students divided into seven classes. Each class consisted of around 48 students. In this research, the writer used only one instrument, it is a questionnaire. The students were asked to respond to several items in the questionnaire about teaching materials of English for Management Business. It has two kinds of questions, closed and open questions. Likert scale with 4 options, namely strongly agree, agree, disagree and strongly disagree, was used in close questions covering materials' attraction, usefulness, level of difficulty, variety, authenticity, and proportion of the four language skills.

\section{Research Findings}

As the data was collected by distributing a questionnaire to the respondents, the results are presented as follows: 


\section{Material Attraction}

\begin{tabular}{lcccc}
\hline \multicolumn{1}{c}{ Statement } & \multicolumn{4}{c}{ Response } \\
\cline { 2 - 5 } & $\begin{array}{c}\text { Strongly } \\
\text { Agree }\end{array}$ & Agree & Disagree & $\begin{array}{c}\text { Strongly } \\
\text { disagree }\end{array}$ \\
\hline $\begin{array}{l}\text { The materials of English for } \\
\text { Management Business II is } \\
\text { interesting for me }\end{array}$ & $15 \%$ & $85 \%$ & - & - \\
\hline Total & & & \\
\hline
\end{tabular}

Table 4.1. The data of material attraction

Based on table 4.1 , it is found that $85 \%$ of respondents agree that the materials of English for Management Business II is interesting for them. While $15 \%$ of students state that they strongly agree to the statement. It means that all respondents are interested in the materials.

\section{Material Usefulness}

\begin{tabular}{|c|c|c|c|c|}
\hline \multirow[t]{2}{*}{ Statement } & \multicolumn{4}{|c|}{ Response } \\
\hline & $\begin{array}{c}\text { Strongly } \\
\text { Agree }\end{array}$ & Agree & Disagree & $\begin{array}{l}\text { Strongly } \\
\text { disagree }\end{array}$ \\
\hline $\begin{array}{l}\text { The materials of English for } \\
\text { Management Business II is } \\
\text { beneficial for me }\end{array}$ & $45 \%$ & $55 \%$ & - & - \\
\hline $\begin{array}{l}\text { The materials of English for } \\
\text { Management Business II is } \\
\text { relevant to current and future } \\
\text { workplace need }\end{array}$ & $42.5 \%$ & $57.5 \%$ & & \\
\hline $\begin{array}{l}\text { The materials of English for } \\
\text { Management Business II helps } \\
\text { me to understand some terms } \\
\text { that I find in other subjects }\end{array}$ & $15 \%$ & $72.5 \%$ & $10 \%$ & \\
\hline $\begin{array}{l}\text { The materials of English for } \\
\text { Management } \quad \text { Business } \\
\text { IIdevelop my English skill }\end{array}$ & $22.5 \%$ & $70 \%$ & $7.5 \%$ & \\
\hline Total & & & & \\
\hline
\end{tabular}

Table 4.2. The data of Material Usefulness

The second item is about material usefulness; whether or not students get benefits from the materials they learn. Table 4.2 above shows that the materials of English for 
Management Business II are advantageous for students. It is proved by the percentage of stating positive response. There are $45 \%$ of the respondents who said they strongly agree and 55\% agree. Furthermore, $42.5 \%$ of students strongly agree and $57.5 \%$ of students agree that the materials are relevant to current and future workplace need. It is useful not only for the future but also for the recent time. From the statement whether the materials of English for Management Business II helps them to understand some terms that they find in other subjects, it is found that $15 \%$ said that strongly agree, $72.5 \%$ agree and only $10 \%$ who disagree. Moreover, most of the respondents give a positive response to the statement that the teaching materials used in the English for Management Business class develop their English skills. It can be seen from the percentage that $22.5 \%$ state strongly agree, $70 \%$ said that they agree and there is only $7.5 \%$ who disagree. In other words, the materials are very useful for students.

\section{Level of difficulty}

\begin{tabular}{lllll}
\hline Statement & \multicolumn{2}{l}{ Response } \\
\cline { 2 - 5 } & $\begin{array}{l}\text { Strongly } \\
\text { Agree }\end{array}$ & Agree & Disagree & $\begin{array}{c}\text { Strongly } \\
\text { disagree }\end{array}$ \\
\hline I think the materials of & $12.5 \%$ & $82.5 \%$ & $5 \%$ & - \\
$\begin{array}{l}\text { English for Management } \\
\text { Business II satisfy with my } \\
\text { competence }\end{array}$ & & \\
\hline Total & $100 \%$ & & \\
\hline
\end{tabular}

Table 4.3. The data of Level of Difficulty

Based on the data in table 4.3, most students said that the materials of English for Management Business II satisfy with their competence. It is proved by the percentage that $95 \%$ saying that they strongly agree $(12.5 \%)$ and most said agree $(82.5 \%)$ to the statement. But, there are $5 \%$ who said that they disagree. In short, the materials are not too difficult nor too easy.

\section{Material Variety}

\begin{tabular}{lllll}
\hline Statement & Response & & \\
\cline { 2 - 5 } & $\begin{array}{l}\text { Strongly } \\
\text { Agree }\end{array}$ & Agree & Disagree & $\begin{array}{l}\text { Strongly } \\
\text { disagree }\end{array}$ \\
\hline $\begin{array}{l}\text { The topics covered in English } \\
\text { for Management Business II }\end{array}$ & $22.5 \%$ & $72.5 \%$ & $5 \%$ & - \\
$\begin{array}{l}\text { is varied } \\
\text { Total }\end{array}$ & & & \\
\hline
\end{tabular}


Table 4.4. Data of Material Variety

According to the respondents, the topics covered in English for Management Business II are varied. This is showed by the percentage of choosing strongly agree and agree which reach $95 \%$. However, there is $5 \%$ of them who said disagree.

\section{Material Authenticity}

\begin{tabular}{lllll}
\hline Statement & Response & & \\
\cline { 2 - 5 } & $\begin{array}{l}\text { Strongly } \\
\text { Agree }\end{array}$ & Agree & Disagree & $\begin{array}{c}\text { Strongly } \\
\text { disagree }\end{array}$ \\
\hline $\begin{array}{l}\text { The materials of English for } \\
\text { Management Business cover }\end{array}$ & & $85 \%$ & - & - \\
authentically daily life topics & & & \\
\hline Total & $100 \%$ & & \\
\hline
\end{tabular}

Table 4.5. Data of Material authenticity

From table 4.5, it can be seen that all respondents confirm that the materials of English for Management Business II is authentic since they cover daily life topics. There are $15 \%$ of respondents who strongly agree and others or $85 \%$ said to agree.

\section{Skills Proportion}

\begin{tabular}{|c|c|c|c|c|}
\hline \multirow[t]{2}{*}{ Statement } & \multicolumn{4}{|l|}{ Response } \\
\hline & $\begin{array}{l}\text { Strongly } \\
\text { Agree }\end{array}$ & Agree & Disagree & $\begin{array}{l}\text { Strongly } \\
\text { disagree }\end{array}$ \\
\hline $\begin{array}{l}\text { The materials of English for } \\
\text { Management Business II have } \\
\text { covered the four English skills } \\
\text { (listening, speaking, reading, } \\
\text { writing) }\end{array}$ & $37.5 \%$ & $55 \%$ & $7.5 \%$ & - \\
\hline $\begin{array}{l}\text { The materials of English for } \\
\text { Management Business II } \\
\text { should have more reading } \\
\text { texts about Business English }\end{array}$ & $20 \%$ & $77.5 \%$ & $2.5 \%$ & \\
\hline Total & $100 \%$ & & & \\
\hline
\end{tabular}

Table 4.6

English learning should involve four language skills, namely listening, reading, speaking and writing. According to the respondents, the materials of English for Management Business II have covered the four English skills. There are 37.5\% who strongly agree and $55 \%$ agree. However, there is $7 \%$ who disagrees. It means that most students approve that the topics are balanced. The second item of this indicator 
is asking about students' opinion whether the course material should have more texts about Business English. It is found that almost all respondents (97.5\%) give a positive response. There is only $2.5 \%$ disagrees. The complete data can be seen in table 4.6.

\section{Students' Perception of Topics of English for Business Management II}

In part 2, the questionnaire puts three open questions asking about students' opinion about which topics should be deleted and which part should be explored more. The other one is about the real advantage the students get after joining the English class.

\begin{tabular}{lll}
\hline No. & Questions & Responses \\
\hline 1. & From the teaching materials of English & Text about the business should be \\
for Business Management II, which added. Listening is too. \\
topic should be more explored? Please \\
mention. & $\begin{array}{l}\text { More discussion about the } \\
\text { vocabulary related to the text }\end{array}$ \\
\hline 2. & $\begin{array}{l}\text { From the teaching materials of English } \\
\text { for Business Management II, which }\end{array}$ \\
& $\begin{array}{l}\text { topic should be reduced? Please } \\
\text { mention. }\end{array}$ \\
\hline After you join the English class, which Job interview \\
materials do you think the most \\
advantageous for you?
\end{tabular}

Table 4.7. Students perception of material's topics

The first question is about topics of the material which should have more exploration. Most respondents expected that business English texts should be added and get a bigger portion. In addition, difficult words nor new terms related to the texts were also discussed. On the other hand, students feel that listening is important too. They said that listening should have more explanation in the class.

The second question is contradictory to the first one. It is about topics which should be reduced. And some students said no topics should be deleted because all of them are needed for their future, but some others state that grammar is too theoretic and they need something which is more practical.

The last question deals with the most advantageous topic for students. In general, many of them said that all topics they learned give benefits. However, surprisingly, most state that a job interview is the most beneficial for them. 


\section{Discussion}

After the data about students' perception of the teaching materials of English for Management Business have been presented, now it is discussed.

\section{Material Attraction}

Table 4.1 shows that all respondents are interested in the materials. It can be proved by the percentage of choosing options strongly agree and agree. 85\% respondents agree that the materials of English for Management Business II is interesting for them. While $15 \%$ of students strongly agree with the statement. It means that the material has a novelty for students. It could be their first time to find such topics like Company Organization, Money, Advertisement, and Employment with different content or tasks. For example in unitAdvertisement, students watched a video of advertisements, discussed a written text about it, then they had to find an advertisement around them to analyze. Probably it was their first experience to do it, but they reckon as an exciting activity. The material is classified as stimulus materials (Hyland, 2006) in (Khoshhal, 2018) that can trigger students' motivation in learning.

\section{Material Usefulness}

Table 4.2 above shows that the materials of English for Management Business II are advantageous for students. It is proved by the percentage of $45 \%$ of the respondents said they strongly agree and 55\% agree. Furthermore, there are $42.5 \%$ of students who strongly agree and $57.5 \%$ of students who agree that the materials are relevant to current and future workplace need. In other words, the materials are very useful for students. The first question of this part is interrelated to the second one. Respondents state that the material gives a lot of advantages for them because they will face it in their workplace. In other words, the materials satisfy their need in their future. Some materials provide knowledge such as Company Organization, Money, Employment, etc. In addition, each topic provides real tasks that become an exciting experience for students. When they must perform Job Interview, previously they got difficulty but they finally could accomplish it since they were challenged to do so. It is useful not only for the future but also for the recent time. From the statement whether the materials of English for Management Business II helps them to understand some terms that they find in other subjects, it is found that $15 \%$ said that strongly agree, $72.5 \%$ agree and only $10 \%$ who disagree. Since the class is designed as English for Specific Purpose, the topics taught are those which belong to the core of their field, in this case, Management Business, as it has been mentioned before. By learning English, students of Management department actually study about their 
major. Take for example, in unit Trade, they learn about types of trading, how people do trading and practice offering and ordering in oral and written communication. Thus, English plays a role as a media. Moreover, in the last part of this item, most of the respondents give a positive response to the statement that the teaching materials used in the English for Management Business class develop their English skills. It can be seen from the percentage that $22.5 \%$ state strongly agree, $70 \%$ said that they agree and there is only $7.5 \%$ who disagree. As a whole, it seems respondents confirm that they improve their English after joining the class comprehensively because the teaching materials provide what they need (Khoshhal, 2018) says that teaching materials must be truly related to the learners' target need. In other words, the materials are very advantageous for students.

\section{Level of Difficulty}

One of the factors influencing students' motivation to learn is a level of difficulty. When the material is too difficult, they will discourage. On the contrary, if it is too easy, students will ignore it. Table 4.3 shows that most students said that the materials of English for Management Business II match with their competence. It is proved by the percentage that $95 \%$ saying that they strongly agree $(12.5 \%)$ and most said agree $(82.5 \%)$ to the statement. But, there are $5 \%$ who said that they disagree. It means that the materials are not too difficult nor too easy. The topics were selected based on some considerations, such as familiarity, authenticity, novelty, and level of difficulty. When a topic is absolutely new and hard, it will make the students unmotivated and have no willingness to come to the class. Spirovska Tevdovska (2016) finds out that in choosing materials language proficiency and students' need become the most dominant considerations.

\section{Material Variety}

Table 4.4 presents that the topics covered in English for Management Business II are varied. This is showed by the percentage of choosing strongly agree and agree which reach $95 \%$. However, there is $5 \%$ of them who said disagree. It means that most of the students admit that the teaching materials have a big variety. It can be seen from the various tasks and activities in the class, such as class survey, games, group discussion, and simulation as what they do a job interview. Furthermore, the language skills distribution in each meeting strengthens this variety which anticipates students' boredom in the class.

\section{Material Authenticity}


Authenticity means the span of being the real life of teaching materials. How presented texts are showing daily life which students can find in their real life. Based on table 4.5, it can be seen that all respondents confirm that the materials of English for Management Business II are authentic since they cover daily life topics. There are $15 \%$ of respondents who strongly agree with and others or $85 \%$ agree that they learned authentic materials in the class. The authentic materials can be seen from some topics taught, such as Advertisement, Money, Employment, etc. Based on the finding, the most authentic topic is a job interview. All respondents were aware that later they will experience it, therefore they tried to do their best. This evidence is relevant to Tomlinson's statement (2012) that teaching material should be authentic to satisfy what learners need in their future and enable them to use the language in real life, as be also Alina \& Lavinia research (2018). They find out that through authentic materials, students can get in the real world due to the use of real language. In addition, Kilickaya (2004) and Alshumaimeri \& Alzyadi (2015) who said that authentic materials are those which can guide learners to use the target language as frequently as possible. In other words, authentic materials give more opportunities for students to expose English with a meaningful context (Spirovska Tevdovska, 2016).

\section{Language Skills Proportion}

Since English has four language skills, they should exist in the teaching-learning process. As the finding reveals that the materials of English for Management Business II have covered the four English skills, it means that all are comprehensively taught in the class. No single skill is missed. It is important to note that "in real communication, more than one skills are used" (Jing quoted in Hungkyo $\&$ Kijay, 2009). Furthermore, there are no skills which are dominantly discussed.

On the other hand, respondents said that they expected to have more reading texts on Business English. It is due to some English terms they found in other subjects that they learn. From this, it seems English becomes more significant function as a knowledge transfer medium. The complete data can be seen in table 4.6.

\section{Students Perception on topics of English for Business Management II}

The second part of the questionnaire deals with topics of English for Business Management II in detail. There are three questions. The first question is about topics of the material which should be discussed and explored more deeply. Most respondents expected that business English texts should be added and get a bigger portion. In addition, difficult words nor new terms related to the texts should also be discussed. It is because their vocabulary has not been sufficient to comprehend the 
topic under discussion. Furthermore, some of them were not supported by a dictionary. This finding shows that students have a big interest in enriching their knowledge of business through English. Consequently, the topics should be selected based on factual and actual consideration. And of course, it is also based on their proficiency level.

Different from the first question, the second question is asking about topics which should be reduced. And many students said no topics should be deleted because all of them are needed for their future. However, some others state that grammar is too theoretic and they need something which is more practical. It is understandable since, in the first semester, they learned dominantly about grammar. Unluckily, what they learn is grammar in isolation, not the language used in an appropriate context. In short, the grammatical items of the material should be selected in terms of practicality and contextuality.

The last question deals with the most advantageous topic for students. Based on the finding, most students state that all topics that they learn are beneficial for them. It reveals that they got something in every lesson they joined. There are five topics covering Company Structure, Advertisement, Money, Trading and Employment. Among them, surprisingly most students feel that Job Interview becomes the most useful material. Although it is more challenging than others, they think that through an interview they experience a very real situation in the class. It means that the language they learn is truly applied in daily life. They not only know terms about employment but also they can apply them in real communication. The video of job interview helps them respond to the situation of the job interview. It is due to most students were full-time students and never experience it, therefore they find it would be very crucial for them to acquire the skill of having a job interview.

\section{Conclusion and Suggestion}

After analyzing the data, finally, some conclusions can be drawn. Based on the finding and discussion, the students' perspective on teaching materials of English for Management Business is positive. They think affirmatively that the materials taught have selected properly in terms of material attraction, usefulness, authenticity, variety, level of difficulty, language skill proportion and the discussed topics. In other words, the materials are appropriate for satisfying Management department students' need to prepare their future. They get many benefits from learning the materials and are challenged to become English proficient.

From the conclusion above, some suggestions are proposed as follows:

1. Teaching materials of English for Management Business II in Economic and Business Faculty of UniversitasMuria Kudus should be annually reviewed and renewed to match with students' need. 
2. It is much better to add more topics for reading texts, particularly about Business English.

3. The vocabulary should be discussed more deeply, not only about the meaning but also the usage in the real context.

4. As it is the most advantageous topic, a job interview should remain in the selected materials.

Due to the limitation of this research where the teaching materials are used only in UniversitasMuria Kudus, further research should be conducted by utilizing them in different colleges and investigate the effectiveness of the materials in supporting students to improve their English proficiency. 


\section{References}

A. Waters, T. H. (1987). English for Specific Purposes: a LearningCenteredApproach.Cambridge. Cambridge University Press.

Algadrie, L. (2002). Needs Analysis: Strategic Issue on the Teaching of English for Specific Purposes for the Study of Sciences and Technology. TEFLIN Journal, 13(1), 106-112. https://doi.org/10.15639/TEFLINJOURNAL.V13I1/106-112

Alina, B.-T., \& Lavinia, N. (2018). The Advantages of Authentic Materials in the ESP/EFL Classroom: Newspaper. "Ovidius” University Cannals, Economics and Sciences Series, XVIII(I).

Alshumaimeri, Y. A., \& Alzyadi, M. S. (2015). Using Material Authenticity in the Saudi English Textbook Design: A Content Analysis from the Viewpoint of EFL Teachers. Advances in Language and Literary Studies, 6(2), 229-241.

Dubin, F., \& Olshtein, E. (2000). Course Design. New York: Cambridge University Press.

Esmer, E., Güven, G., Aydın, O., Özden, B., Efe, K., \& Şener, N. (2016). Perception of Education Faculty Students on Teaching Method \&amp; Materials. Academic Journals, 11(12), 1093-1109. https://doi.org/10.5897/ERR2016

Farani, Y. (2017). ESP Business English: The Proposed Students' Workbook Used for Teaching Bahasa Inggris Bisnis at D3 Accounting of Economics \&amp; Bussiness Faculty at UNMER Malang. EnJourMe (English Journal of Merdeka) : Culture, Language, and Teaching of English, 2(1), 61-71. https://doi.org/10.26905/enjourme.v2i1.631

Hungkyo, J., \& Kijay, J. (2009). The effect of Integrated and Segregated Skills Approach on English Language Acquisition among Freshmen Nursing \& Business Students in Mission College Thailand. The Scriptor, Journal of Arts \& Humanities Department Thailand.

Hyland, K. (2006). English for Academic Purpose. An Advanced Resource Book. New York: Routledge.

Khoshhal, Y. (2018). The Role of Teaching Materials in the ESP Course: A Case of Business English (Finance and Economics). Journal of Humanistic and Social Studies, IX(1).

Kilickaya, F. (2004). Authentic Materials and Cultural Content in EFL Classrooms. The Internet TESL Journals, X(7). 
52 | VISION: JOURNAL FOR LANGUAGE AND FOREIGN LANGUAGE LEARNING

Liau, H. C., \& Chen, Y. S. (2012). English for Science and Technology Teahing Materials: One Phase Evaluation. IETC Conference. Taoyuan: National Central University, Taiwan.

Spirovska Tevdovska, E. (2016). Authentic Material vs Textbooks in ESP (English for Specific Purposes). Journal of English for Specific Purposes, 5(1). 